\title{
Study of Student Satisfaction Level in the Faculty Based on Performance Assessment and Interest Level
}

\author{
Achmad Fauzan", Muhammad Hasan Sidiq K, Jaka Nugraha \\ Program Studi Statistika FMIPA Universitas Islam Indonesia, Yogyakarta, 55584 \\ *achmadfauzan@uii.ac.id
}

\begin{abstract}
A procedure to evaluate various services in a university is student satisfaction level. Purpose of this study is to measure the level of student satisfaction in the university environment, particularly in the Faculty of Mathematics and Natural Sciences, Universitas Islam Indonesia (FMIPA UII) and future expectations of students focusing on their respective study programs. 6 aspects were used to find out how much satisfaction the students had, namely: (1) tangible, (2) reliability, (3) responsiveness, (4) assurance, (5) empathy, and (6) information. Descriptive analysis method was utilized for satisfaction represented by the Cartesian diagram. The study was conducted in a period of 3 months with the sample used being active students in the 2016 and 2017 FMIPA classes proportionally in each study program (study program). The data used are primary data consisting of 2 main assessments, namely performance assessment and importance assessment. The results of the level of satisfaction / suitability are classified into the Cartesian diagram which consists of 4 priorities, namely: top priority, achievement priority, low priority, and excessive. The results of the study obtained overall levels of satisfaction in Mathematics as much as $90 \%$ of students were satisfied with the level of performance provided. However, there are still 2 indicators that are included in the priority, namely problems in the key-in process and ease of communication for parents of students to consult. In addition to the contents of each indicator, an analysis of suggestions for improvement in the FMIPA environment using text mining based on barplot and wordcloud is associated with the dominant words appearing to describe the general expectations of students.
\end{abstract}

Keywords: performance; importance; cartesian diagram.

\begin{abstract}
ABSTRAK
Salah satu cara untuk mengevaluasi berbagai layanan di universitas adalah dilihat dari tingkat kepuasan mahasiswa. Tujuan dari penelitian ini adalah mengukur seberapa besar tingkat kepuasan mahasiswa di lingkungan Universitas khususnya di lingkungan Fakultas Matematika dan Ilmu Pengetahuan Alam Universitas Islam Indonesia (FMIPA UII) serta harapan kedepannya dari mahasiswa fokusnya di prodinya masing-masing. Digunakan 6 aspek untuk mengetahui seberapa besar tingkat kepuasan dari mahasiswa, yakni: (1) Tangible, (2) Reliability, (3) Responsiveness, (4) Assurance, (5) Empathy, dan (6) Information. Metode penelitian yang digunakan adalah metode deskriptif analisis terkait kepuasan yang direpresentasikan oleh diagram kartesius. Penelitian dilakukan dalam kurun waktu 3 bulan dengan sampel yang digunakan adalah mahasiswa aktif di lingkungan FMIPA angkatan 2016 dan 2017 secara proporsional disetiap program studi (prodi). Adapun data yang digunakan adalah data primer yang terdiri dari 2 penilaian utama, yakni penilaian kinerja (performance) dan penilaian tingkat kepentingan
\end{abstract}

Study of Student Satisfaction Level in the Faculty Based on Performance

Assessment and Interest Level 
(importance). Hasil dari tingkat kepuasan/kesesuaian diklasifikasikan kedalam diagram kartesius yang terdiri atas 4 prioritas, yakni: prioritas utama, prioritas prestasi, prioritas rendah, dan berlebihan. Hasil dari penelitian diperoleh secara keseluruhan tingkat kepuasan diMIPA sebesar 90\% mahasiswa sudah puas terhadap tingkat kinerja yang diberikan. Akan tetapi, masih terdapat 2 indikator yang masuk dalam prioritas yakni permasalahan dalam proses pengambilan mata kuliah (key-in) dan kemudahan komunikasi bagi orangtua mahasiswa untuk berkonsultasi. Disamping isian dari masing-masing indikator, dilakukan pula analisis dari saran untuk perbaikan dilingkungan FMIPA dengan menggunakan text mining berdasarkan barplot dan wordcloud yang diasosiasikan dengan kata yang dominan muncul untuk mengetahui gambaran umum harapan dari mahasiswa.

Kata kunci: penilaian kinerja, tingkat kepentingan, tingkat kepuasan, diagram kartesius.

\section{Pendahuluan}

Dinamisasi perubahan zaman menjadikan adanya perbaikan yang kontinu. Salah satu aspek untuk melakukan perbaikan tersebut diantaranya melakukan evaluasi dari upaya yang sudah dilaksanakan. Apabila dikaitkan dengan lingkup Perguruan Tinggi (PT) salah satu bentuk evaluasi yang dilakukan adalah dari sisi kepuasan mahasiswa terhadap berbagai pelayanan yang diberikan.

Dalam PT, sejauh mana keberhasilan pelayanan yang diberikan dapat diukur diantaranya dengan seberapa puas mahasiswa atau seberapa besar pelayanan tersebut sudah dirasakan mahasiswa. Pelayanan dikatakan baik apabila pelayanan tersebut sesuai dengan aturan dan dapat memuaskan mahasiswa. Kepuasan dari pelanggan memiliki makna yang beragam dan tidak selamanya kepuasan berbentuk uang, melainkan lebih didasarkan pada pemenuhan perasaan tentang yang dibutuhkan. Kartono (1987) menyatakan uang tidak selalu menjadi motif primer bagi seseorang, melainkan kebanggaan dan minat yang besar terhadap sesuatu yang memberikan kepuasan tersendiri. Begitu pentingnya dari kepuasan pelanggan, bahkan Mittal dan Kamura (2001) menyatakan kepuasan dari pelanggan adalah kunci dari seorang pelanggan untuk pembelian di masa depan.

Oleh karena itu, PT harus mengetahui kebutuhan dan keinginan dari mahasiswa. Suatu produk dikatakan bermutu apabila produk tersebut dapat memenuhi kebutuhannya (Supranto, 2006). Ketika pelayanan diberikan maksismal maka konsumen (dalam hal ini adalah mahasiswa dan pengguna alumni) di suatu PT akan memberikan hasil yang optimal pula.

Peneliti mendefinisikan kualitas pelayanan berdasarkan teori yang 
berbeda-beda. Sebagai contoh, Siami (2012) mendefinisikan kualitas layanan sebagai pemahaman umum dari pelanggan atau kesesuaian dan ketidaksesuaian relatif dari suatau organisasi dan pelayanan dari organisasi tersebut. Parasuraman et al. (1985) mendefinisikan bahwa kualitas layanan penilaian global atau sikap terhadap keunggulan yang diberikan. Selain itu penilaian kualitas layanan merupakan pencerminan status dan perbedaan antara pengamatan pelanggan dan harapan (Motefakker, 2016). Kemudian Kotler (2000) menyederhanakan konsep kepuasan menjadi 5 faktor yang digunakan sebagai indikator pelayanan jasa, yakni:

1 tangible (bukti langsung)

Diantaranya perlengkapan, pegawai, fasilitas fisik, dan sarana komunikasi.

2 reliability (reliabilitas)

Kemampuan untuk memberikan pelayanan sesuai dengan yang dijanjikan secara akurat, segera, dan memuaskan.

3 responsiveness (daya tanggap)

Seberapa besar staff atau karyawan dalam membantu para pelanggan dan memberikan layanan dengan tanggap.

4 assurance (jaminan)
Meliputi kompetensi, pengetahuan, kesopanan, dan sifat dapat dipercaya dari pihak pemberi layanan.

5 empathy (Empati)

Meliputi kemudahan didalam menjalin relasi, perhatian pribadi, komunikasi yang baik serta pemahaman atas kebutuhan individu setiap pelanggan.

Penelitian ini merupakan pengembangan dari penelitian sebelumnya, seperti Suryana (2014) yang mengkaji tentang rata-rata tingkat kepuasan mahasiswa dan selisih (gap) antara harapan dan kepuasan yang dirasakan oleh mahasiswa terhadap pelayanan pendidikan di Jurusan PGPAUD, maupun penelitian Rahmawati (2013) yang mengkaji faktor-faktor yang mempengaruhi kepuasan mahasiswa yang hasilnya paling dominan adalah profesionalisme dosen dan juga penelitian Wei dan Ramalu (2011)yang mengkaji hubungan antara kualitas layanan dan tingkat kepuasan siswa.
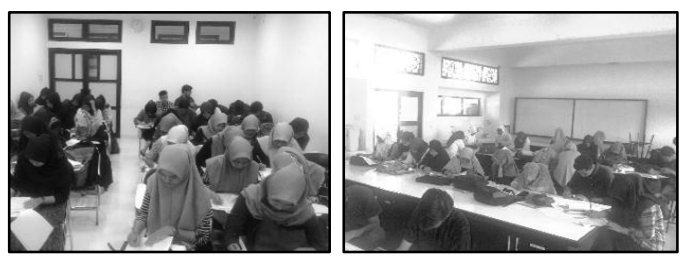

Gambar 1. Pengambilan data

Study of Student Satisfaction Level in the Faculty Based on Performance Assessment and Interest Level 


\section{Metode Penelitian}

Penelitian dilaksanakan dalam kurun waktu 3 bulan (Oktober sampai Desember 2018) di lingkungan Fakultas Matematika dan Ilmu Pengetahuan Alam Universitas Islam Indonesia (FMIPA UII). Metode penelitian yang digunakan adalah metode deskriptif analisis, yakni penelitian yang bertujuan untuk memberikan gambaran ataupun menjelaskan keadaan dari objek penelitian yang didasarkan data dan fakta pada saat dilakukan penelitian serta memberikan interpretasi secara rasional tentang berbagai kinerja yang diberikan oleh FMIPA dan tingkat kepuasan mahasiswa (Nassaji, 2015). Data yang diperoleh merupakan data primer dari penyebaran kuesioner kepada mahasiswa. Kuesioner yang digunakan bersifat tertutup, yakni masing-masing butir pertanyaan yang diajukan kepada responden sudah diberikan pilihan jawabannya.

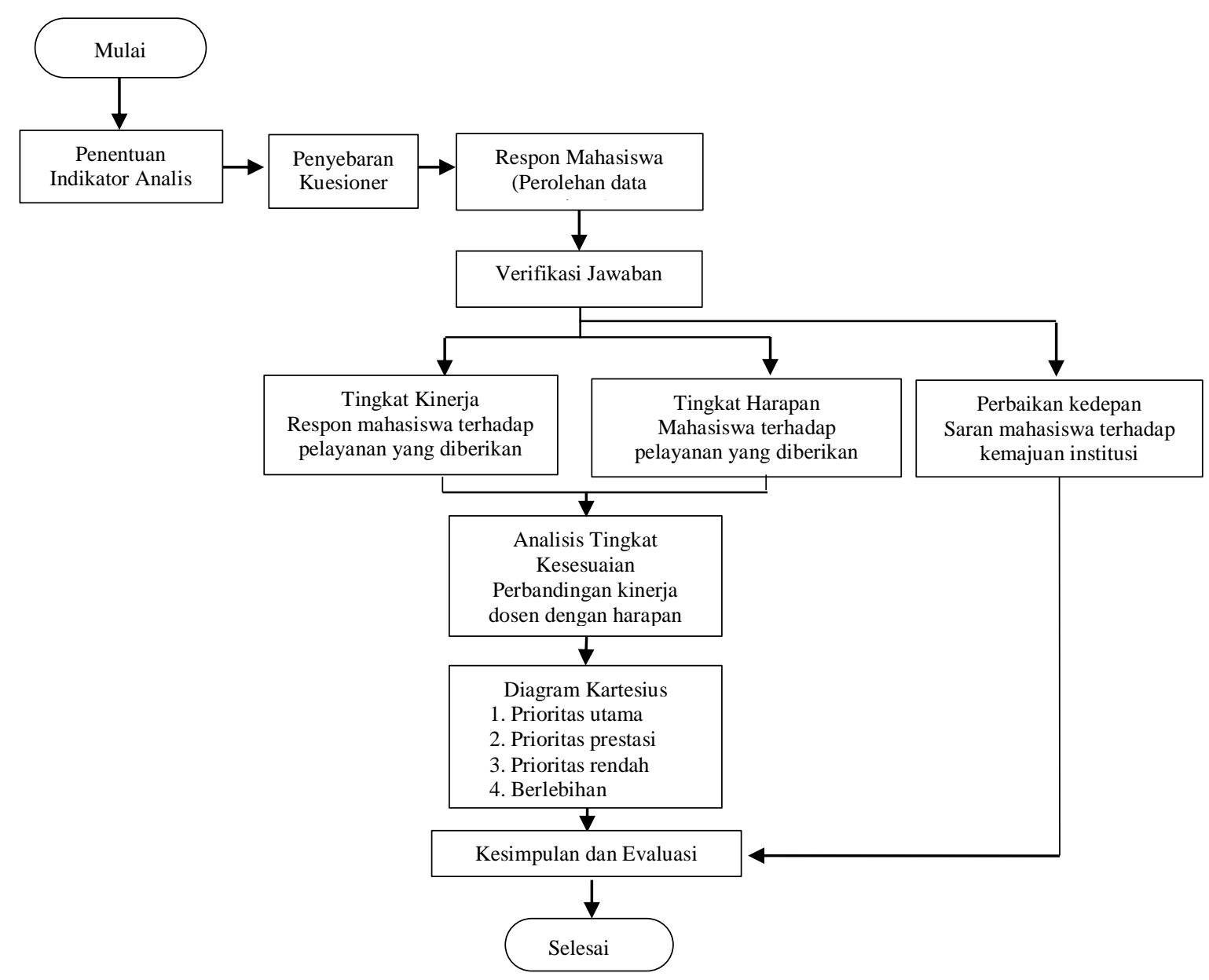

Gambar 2. Diagram alir penelitian 
Dari kuesioner yang diberikan, diperoleh skor jawaban dari masingmasing pertanyaan yang diberikan. Populasi dalam penelitian ini adalah mahasiswa aktif Fakultas MIPA UII di semua prodi (Statistika, Kimia, Farmasi, Analis Kimia, dan Pendidikan Kimia) angkatan 2016 dan 2017. Dipilih 2 angkatan tersebut karena mahasiswa angkatan tersebut minimal sudah 1 tahun menerima pelayanan yang sudah diberikan oleh pihak Fakultas, sehingga hasilnya lebih representatif dan tidak bias. Diagram alir penelitian disajikan pada Gambar 2.

Sampel diambil dari populasi menggunakan probability sampling yakni dengan metode random sampling. Sampel penelitian diambil dari populasi dengan menggunakan rumus pada Persamaan 1 (Yamane, 1967).

$n=\frac{N}{1+N(e)^{2}}$

keterangan:

$\mathrm{n}$ : sampel responden;

$\mathrm{N}$ : jumlah populasi;

e : tingkat error.

Dari indikator pelayanan Kotler (2000), indikator penelitian dari tingkat kesesuaian/kepuasan mahasiswa diidentifikasi sebagai berikut.

a. Reliability

Difokuskan pada kehandalan tenaga pendidik (dosen), diantaranya:

1. Penilaian proses belajar mengajar $(1)^{1}$.

2. Persiapan materi yang diberikan (2).

3. Kesungguhan dalam proses perkuliahan (3).

4. Soal ujian yang diberikan (4).

5. Materi yang diberikan dalam peningkatan kemampuan dan keterampilan (5).

6. Pekerjaan Rumah/Tugas/Bahan diskusi (6).

7. Usaha dalam menarik mahasiswa (7).

8. Bahan ajar yang diberikan (8).

9. Nilai yang diberikan (9).

10. Proporsi nilai yang diberikan (10).

b. Tangibles

Meliputi sarana Pendidikan (alat perkuliahan, media pengajaran, dan prasarana Pendidikan), diantaranya:

1. Kenyamanan ruang kuliah (11).

2. Kebersihan ruang perkuliahan (12).

3. Laboratorium yang diberikan (13).

4. Ketersediaan referensi di perpustakaan (14).

5. Ketersediaan fasilitas kamar kecil (15).

6. Fasilitas ibadah (16).

7. Prosedur terkait layanan akademik (17).

8. Kelengkapan informasi kurikulum (18).

9. Kemudahan pengambilan mata kuliah (key-in) (19).

\footnotetext{
${ }^{1}$ Nomor didalam tanda kurung ( ) merupakan nomor di kuesioner.
}

Study of Student Satisfaction Level in the Faculty Based on Performance

Assessment and Interest Level 
10. Keragaman mata kuliah yang disediakan (20).

c. Responsiveness

Meliputi sikap tanggap prodi yang diberikan kepada mahasiswa, diantaranya:

1. Kepedulian prodi bagi mahasiswa yang kurang mampu dan berprestasi (21).

2. Sikap tanggap dalam membantu mahasiswa menghadapi masalah akademik (22).

3. Komunikasi orangtua berkonsultasi (23).

4. Dukungan kegiatan kemahasiswaan (24).

5. Dukungan kemajuan mahasiswa, meliputi konferensi, perlombaan, seminar, dll (25).

6. Kecepatan dalam pelayanan mahasiswa (26).

d. Assurance

Meliputi perlakuan terhadap mahasiswa, diantaranya:

1. Kesantunan staf administrasi (27).

2. Komunikasi Dosen pembimbing Akademik (DPA) terkait permasalahan mahasiswa (28).

3. Efisiensi waktu dosen dalam pengajaran (29).

4. Relevansi usaha dengan hasil yang diterima oleh mahasiswa (30).

5. Sanksi atas pelanggaran (31).

e. Empathy

Berkaitan dengan pemahaman terhadap kepentingan mahasiswa, diantaranya:
1. Kepedulian prodi terhadap kepentingan dan kesulitasn mahasiswa (32).

2. Proses monitoring dan evaluasi terhadap kemajuan mahasiswa (33).

3. Sifat kooperatif dan transparansi antara dosen dengan mahasiswa (34).

4. Usaha prodi dalam memahami dan mengembangkan minat bakat mahasiswa (35).

f. Informasi

Meliputi sistem yang sudah berjalan di linkungan FMIPA, diantaranya:

1. Kemudahan akses informasi sistem perkuliahan berupa buku panduan perkuliahan serta melalui pengumuman (36).

2. Kemudahan akses informasi akademik dan pelayanan non akademik secara daring (37).

3. Keterbukaan informasi dan pelayanan (38).

4. Layanan pengaduan bagi mahasiswa (39).

5. Respon atas pengaduan mahasiswa (40).

Dari kuesioner yang dirancang, dilakukan pengukuran bobot jawaban dengan menggunakan skala Likert. Skala Likert menyatakan seperangkat pernyataan (item) ditawarkan untuk situasi nyata atau hipotetis sedang dipelajari. Responden diminta menunjukkan tingkat persetujuan (dari sangat tidak setuju sampai sangat setuju) dengan pernyataan yang diberikan (item) pada skala metrik 
(Joshi et al. (2015)). Adapun data yang diperoleh dari kuesioner merupakan data ordinal yang terdiri dari 2 penilaian utama, yakni penilaian kinerja (performance) dan penilaian tingkat kepentingan (importance). Detail dari masing-masing penilaian memiliki tingkatan skor sebagai berikut.

Penilaian kinerja (performance), terdiri dari: Tidak memuaskan (1), Kurang memuaskan (2), Cukup memuaskan (3), Memuaskan (4), dan Sangat memuaskan (5). Sementara enilaian tingkat kepentingan/harapan (importance), meliputi: Sangat tidak penting (1), Tidak penting (2), Kurang penting (3), Penting (4), dan Sangat penting (5).

Pengukuran tingkat kepuasan digunakan analisis tingkat harapan dan tingkat kinerja (informanceperformance analysis), adapun langkahnya adalah sebagai berikut:

1. Pembuatan tabulasi data

Pembuatan tabulasi dilakukan dari data primer yang diperoleh kemudian disesuaikan dengan tingkat kinerja dan tingkat kepentingan.

2. Perhitungan skor

Setelah data ditabulasikan sesuai dengan rancangan yang disiapkan, langkah berikutnya adalah perhitungan skor ataupun persentase jawaban serta memberikan interpretasi secara proporsional dan rasional.

3. Hitung tingkat keseuaian

Tingkat kesesuaian dihitung dengan menggunakan rumus yang disajikan pada Persamaan 2 (Nasution, 2001)

$T K=\frac{x}{y} \times 100 \%$

keterangan:

TK : tingkat kesesuaian responden

$x \quad$ : skor penilaian kinerja

$y \quad$ : skor penilaian kepentingan.

4. Perhitungan indikator

Tahapan perhitungan indikator langkahnya adalah sebagai berikut.

4.1. Membandingkan hasil dari tingkat kinerja dan tingkat harapan (informance-performance analysis), kemudian dilakukan interpretasi secara proporsional dan rasional.

Visualisasi dari (informanceperformance analysis) dengan menggunakan diagram kartesius. Diagram kartesius adalah bagan yang terdiri dari 4 (empat) bagian dimana masing-masing bagian dibatasi 2 (dua) garis yang berpotongan tegak lurus pada titik $(x, y) . x$ merupakan nilai rata-rata dari skor tingkat kinerja dan $y$ merupakannilai rata-rata dari skor tingkat kepentingan/harapan. Ilustrasi dari diagram kartesius disajikan pada Gambar 3. 


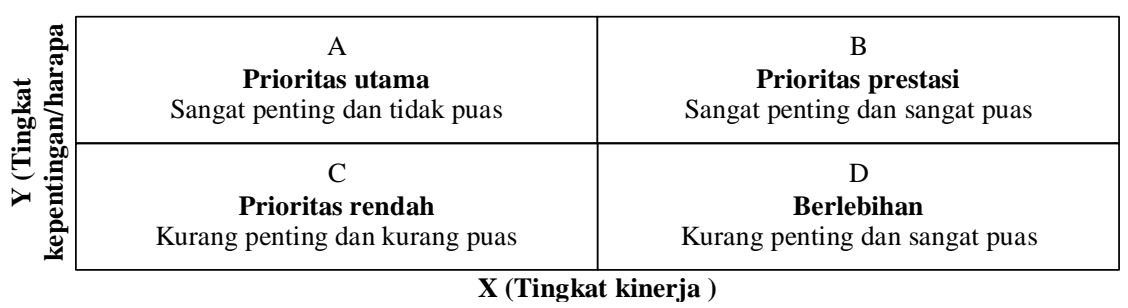

Gambar 3. Diagram Kartesius (sumber: Nasution, 2001:59)

keterangan:

a. Daerah A merupakan prioritas utama yang harus diperbaiki, hal ini dikarenakan tingkat kepentingan/ harapan pada daerah ini sangat besar namun tingkat kinerja yang sudah dilakukan masih kecil. Dapat juga dikatakan daerah A merupakan kondisi yang masih mengecewakan atau tidak memuaskan.

b. Daerah B merupakan prioritas prestasi. Pada daerah ini dapat dijelaskan bahwa tingkat kinerja sudah sesuai dengan tingkat kepentingan/harapan yang diinginkan. Daerah ini dapat juga dikatakan kondisi yang sangat penting dan sangat memuaskan.

c. Daerah C merupakan prioritas rendah. Daerah ini menunjukan beberapa faktor-faktor yang tidak terlalu penting bagi mahasiswa dan tingkat kinerja yang dilakukan juga biasa saja. Daerah ini mencerminkan kondisi yang kurang memuaskan dan kurang penting.

d. Daerah D merupakan prioritas yang berlebihan. Daerah ini menunjukan tingkat kepentingan yang kurang penting namun tingkat kinerjanya berlebihan. Dapat juga dikatakan di daerah D merupakan kondisi yang kurang penting, namun pelaksanaannya sangat memuaskan.

\section{Hasil dan Pembahasan}

Sesuai dengan rancangan yang direncanakan, penelitian dilaksanakan dalam kurun waktu 3 bulan. Diperoleh data sebanyak 579 responden yang tersebar secara proporsional dari masing-masing prodi. Dari hasil yang diperoleh nantinya akan dijelaskan tingkat kepuasan secara keseluruhan di FMIPA yang kemudian diperinci tingkat kepuasan masing-masing prodi. Kemudian diperkuat saran secara umum yang diharapkan dari mahasiswa di lingkungan FMIPA.

Dari 40 indikator yang diberikan, tingkat kesesuaian di lingkungan FMIPA memiliki rentang sebesar 77.01 $\%$ sampai $97.37 \%$ dengan rata-rata tingkat kesesuaiannya/kepuasannya sebesar $90.24 \%$. Secara visual tingkat kesesuaian di FMIPA dan masingmasing prodi disajikan pada Gambar 4. 


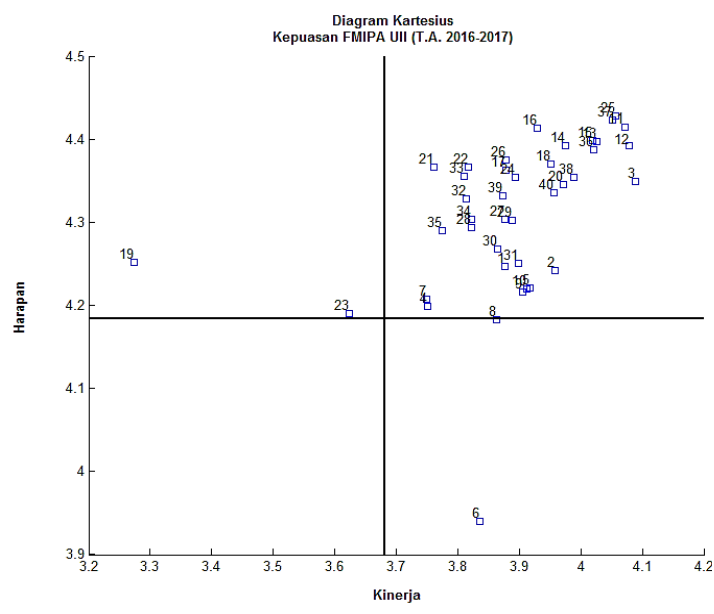

(a) Diagram Kartesius FMIPA

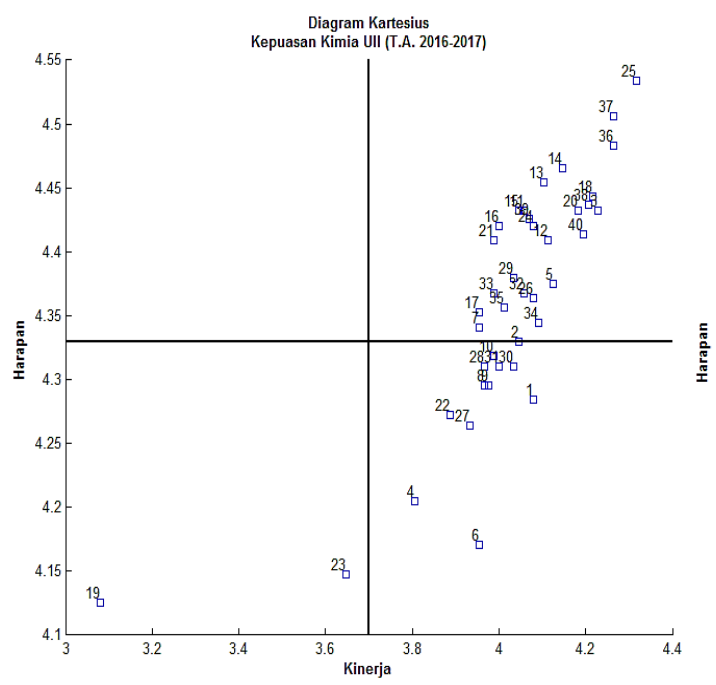

(c) Program Studi Kimia

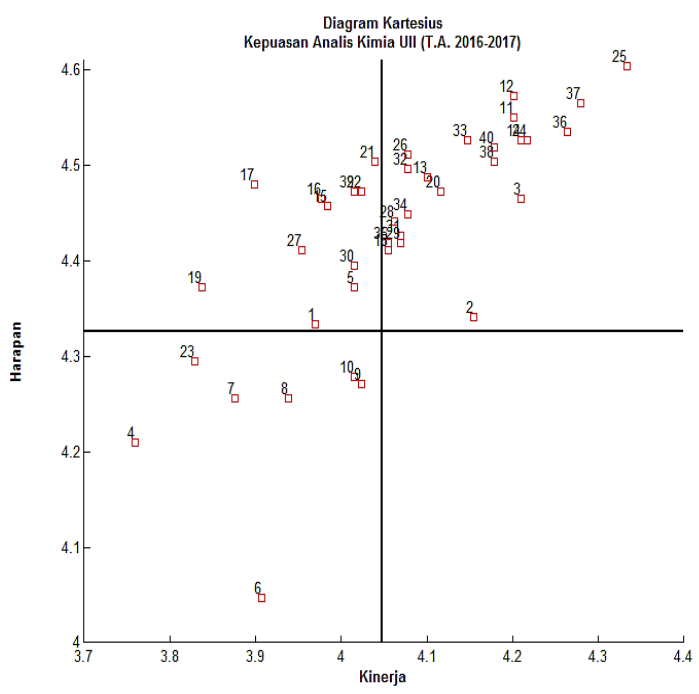

(e) Program Studi Analis Kimia

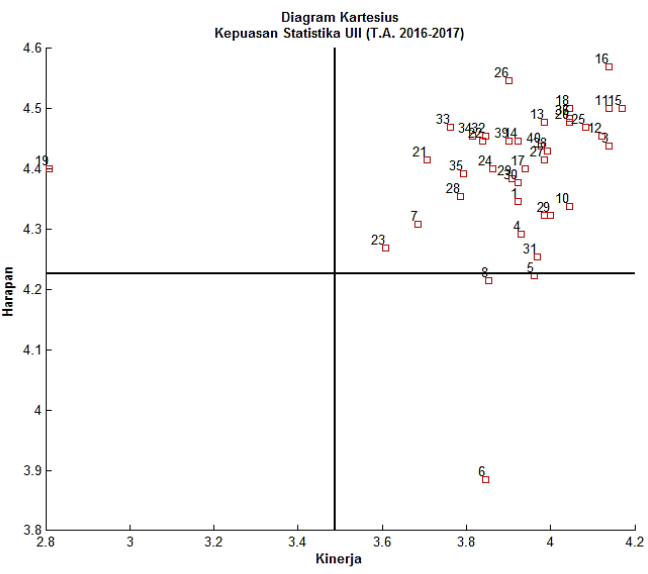

(b) Prodi Statistika

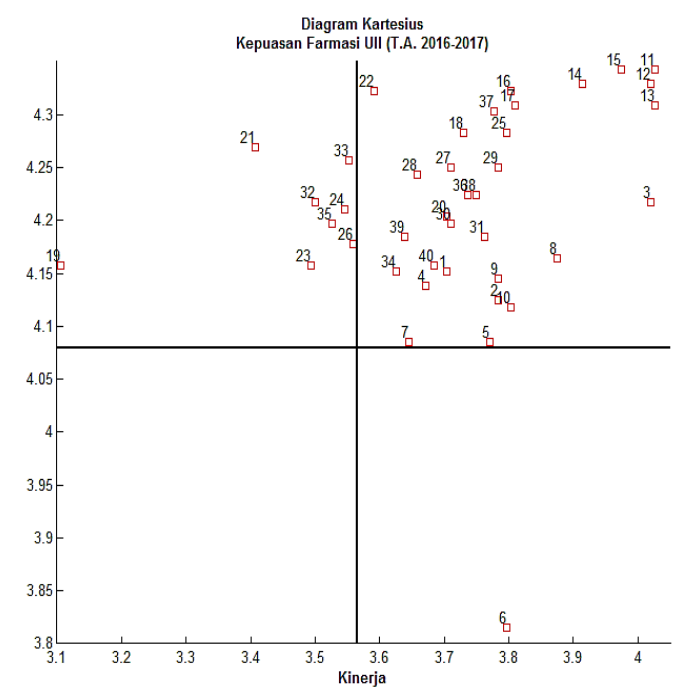

(d) Program Studi Farmasi

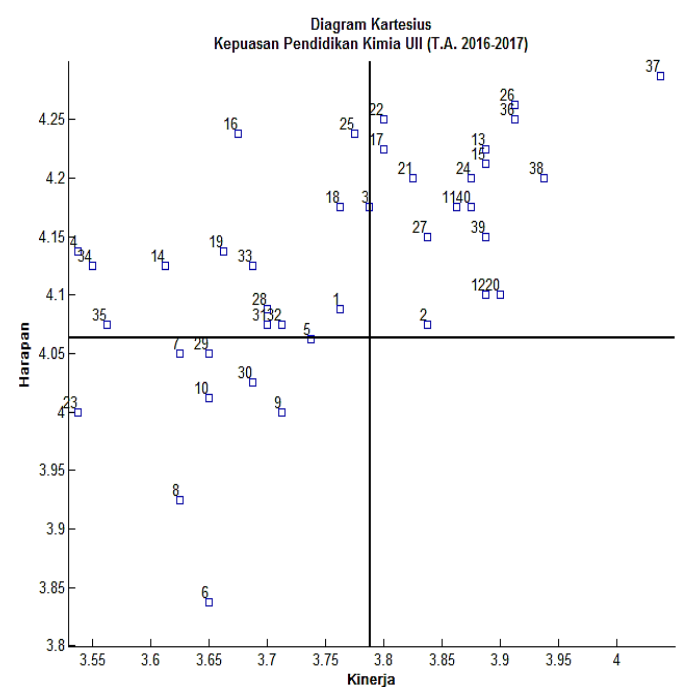

(f) Program Studi Pendidikan Kimia

Gambar 4. Tingkat kesesuaian/kepuasan di lingkungan Fakultas MIPA

Study of Student Satisfaction Level in the Faculty Based on Performance Assessment and Interest Level 
Pembahasan dari masing-masing gambar adalah sebagai berikut. Secara keseluruhan, tingkat kesesuaian/kepuasan dari FMIPA (berdasarkan gambar bagian (a)), nampak sebanyak 36 indikator sudah terdapat didalam bagian prioritas prestasi atau dapat dikatakan sebesar 90\% mahasiswa sudah puas terhadap tingkat kinerja yang diberikan. Sementara sisanya 2 indikator masuk dalam kategori prioritas utama dan 2 indikator lagi masuk kedalam bagian berlebihan.

Dua indikator yang masuk dalam prioritas utama dijelaskan oleh indikator nomor 19 dan 23, yakni permasalahan dalam proses pengambilan mata kuliah (key-in) (19) dan kemudahan komunikasi bagi orangtua mahasiswa untuk berkonsultasi (23).

Dengan masuknya indikator 19 sebagai salah satu prioritas utama, maka diharapkan FMIPA dapat memperbaiki proses key-in dari segi sistem maupun waktu key-in, hal ini dikatenakan tidak sedikit mahasiswa yang mengalami kendala dalam proses pengambilan mata kuliah mulai dari kesulitan pengambilan mata kuliah maupun kepastian mata kuliah yang diberikan. Disamping proses key-in pada waktu pengambilan mata kuliah, pihak Fakultas juga perlu mempersiapkan dengan mata terkait key-in ketika remidial, karena tidak sedikit mahasiswa yang hendak remidial namun belum bisa ambil atau terlewat dalam proses pengambilan karena waktunya singkat dan terbatas.

Sementara indikator 23 menjelaskan masih minimnya komunikasi dari pihak Fakultas. Indikator 23 ini dapat dijadikan sebagai bahan evaluasi lingkungan Fakultas untuk mengadakan adanya wadah baik berupa online atau offline yang memudahkan orangtua menghubungi pihak Fakultas.

Disisi lain, masih terdapat 2 indikator yang masuk dalam kategori berlebih yakni kelebihan dalam hal pekerjaan rumah dan bahan referensi yang diberikan. Hal ini cukup menarik karena ternyata sesuatu yang baik untuk mahasiswa tidak selamanya baik diterima baik pula oleh mahasiswa.

Dari sisi keyakinan mahasiswa memilih prodi di Fakultas MIPA diperoleh nilai yang cukup besar, yakni sebesar 77.38 dan nilai kepuasan yang sudah dirasakan dalam kurun waktu minimal 1 tahun sebesar 78.81. Artinya, secara keseluruhan pelayanan yang diberikan kepada mahasiswa sudah 
cukup besar dan mahasiswa sudah cukup puas, karena sudah lebih dari nilai 75 pada tingkat kepuasan pada umumnya. Kendati demikian, masih terdapat nilai yang belum dioptimalkan dan ini dapat menjadikan perbaikan bagi Fakultas. Tingkat kepuasan kemudian diperinci untuk masingmasing prodi.

Tingkat kepuasan prodi Statistika disajikan (Gambar 4 bagian b) dari 40 indikator, sebesar $90 \%$ termasuk dalam kategori prioritas prestasi, dan $10 \%$ terbagi atas prioritas utama dan kategori berlebihan. Di Prodi Statistika yang masih menjadi permasalahan adalah masih sulitnya dalam proses pengambilan mata kuliah (key-in) indikator nomor 19. Hal ini menjadi permasalahan klasik dan rutinitas di prodi Statistikam diantaranya masih banyaknya mata kuliah yang beririsan, kuota banyaknya mahasiswa yang berlebih, dan waktu pelaksanaan key-in yang terbatas.

Selain itu, tidak jarang pada waktu key-in masih membutuhkan proses yang tidak singkat atau belum efisien yang disebabkan banyak faktor diantaranya adalah banyaknya mahasiswa yang mengakses dalam waktu yang relatif bersamaan. Dari kuesioner diperoleh nilai rata-rata keyakinan di prodi Statistika sebesar 85.56 atau cukup besar dan nilai kepuasan sebesar 83.97. Dari hasil tersebut, dapat diinterpretasikan bahwa kepuasan mahasiswa di prodi ini sudah cukup besar kendati masih terdapat sedikit indikator yang perlu diperbaiki.

Prodi Kimia (Gambar 4 bagian c) secara keseluruhan dari 40 indikator terbagi atas 26 masuk dalam prioritas prestasi, 2 prioritas rendah, dan 12 kategori berlebihan. Indikator yang masuk dalam kategori prioritas rendah di prodi Kimia adalah kemudahan dalam proses pengambilan mata kuliah (key-in) dan kemudahan orangtua untuk berkonsultasi dengan prodi. Karena ke2 indikator tersebut masuk kategori prioritas rendah maka dapat dikatakan kedua masalah tersebut bukanlah masalah utama yang ada di prodi Kimia atau masih dalam kategori yang masih dapat ditolerir dan bukan masalah utama.

Sementara itu, yang berada dikategori berlebih adalah indikator ke $1,2,4,6,8,9,10,22,27,28,30$, dan 31. Keterangan dari masing-masing nomor indikator dijelaskan pada bagian metode penelitian tentang indikator kepuasan mahasiswa. Dari rentang 0 sampai 100, diperoleh nilai rerata keyakinan mahasiswa yakin memilih 
prodi kimia saat ini sebesar 79.65 (tergolong cukup besar), hal ini juga dikuatkan dari kepuasan yang sebesar 82.75 .

Tingkat kesesuaian prodi Farmasi disajikan pada Gambar 4 bagian d. Sebesar $77.5 \%$ mahasiswa menyatakan puas dari tingkat kinerja yang telah diberikan oleh prodi. Dari 40 indikator, sebanyak 31 indikator berada dalam prioritas prestasi, namun masih terdapat 8 indikator yang berada di prioritas utama (kurang memuaskan), yakni nomor $19,21,23,24,26,32,33$, dan 35. Untuk indikator 19 hampir sama dengan permasalahan yang ada di prodi lain sehingga perlu adanya perbaikan dalam manajemen pada proses pengambilan mata kuliah (key-in).

Kemudian, prodi Farmasi perlu adanya evaluasi secara internal dengan mahasiswa baik komunikasi langsung dari prodi terhadap mahasiswa maupun terhadap orangtua mahasiswa di prodi Farmasi. Kemudian perlu adanya proses evaluasi terhadap kemajuan mahasiswa dalam rangka mendorong perbaikan yang ada di prodi Farmasi, diantaranya dapat berupa rutinitas workshop atau pelatihan dalam meningkatkan kemajuan mahasiswa. Nilai keyakinan mahasiswa setelah ketrima di prodi Farmasi sebesar 76.58 dan nilai kepuasan sebesar 77.67. Nilai ini tergolong cukup baik karena sudah lebih dari 75 (atau 75\%) mahasiswa yakin dan puas atas layanan yang sudah diberikan.

Prodi Analis Kimia (Gambar 4 bagian e) memiliki tingkat kesesuaian/kepuasan yang beragam yakni sebesar 11 indikator termasuk dalam prioritas utama, 22 masuk dalam prioritas prestas, dan 7 indikator masuk dalam prioritas rendah. Adapun yang berada dalam prioritas utama di prodi Analis Kimia, yakni indikator nomor 1, $5,15,16,17,19,21,22,27,30$, dan 39 . Dapat dilihat bahwa prodi analis kimia secara keseluruhan masih ada yang perlu dioptimalkan, baik dari aspek reliability, tangibles, responsiveness, empathy, dan information.

Dari aspek tangibles perlu ditingkatkan fasilitas yang disediakan misalnya kamar kecil dan tempat ibadah. Kemudian dari aspek responsiveness perlu ditingkatkan kepedulian dari prodi terhadap kemajuan dan perkembangan mahasiswa. Hal ini dikarenakan pada indikator 39 mahasiswa masih membutuhkan atau masih kurang puas atas layanan pengaduan bagi mahasiswa yang mengalami peramsalahan. 
Selain ke-11 masalah utama diatas, terdapat 7 indikator yang tergolong prioritas rendah diidentifikasikan dari nomor 4, 6, 7, 8, 9, 10, dan 23. Kemudian secara keseluruhan, nilai keyakinan mahasiswa setelah 1 tahun di prodi memiliki nilai yang besar yakni sebesar 84.53 dan mahasiswa yakin di prodi tersebut sebesar 85.02. Adapun standar deviasinya sebesar 15.86 dan tergolong memiliki nilai standar deviasi yang kecil. Atau dalam artian, nilai dari mahasiswa keseluruhan berkisar 70 hingga 100 baik dari sisi keyakinan maupun kepuasan.

Prodi Pendidikan kimia (Gambar 4 bagian f) merupakan prodi yang termuda sehingga wajar dari 40 indikator diperoleh prioritas utama dan prioritas prestasi hampir berimbang yakni sebanyak 15 masuk dalam kategori prioritas utama dan sebanyak 17 indikator masuk dalam indikator prestasi. Ke-15 prioritas utama dari prodi Pendidikan kimia tersebar secara merata, yakni 1, 3, 4, 5, 14, 16, 18, 19, $25, \quad 28,31,32,33,34$, dan 35 . Sementara yang berada di prioritas prestasi adalah indikator nomor: 2, 11, $12,13,15,17,20,21,22,24,26,27$, 36, 37, 38, 39, dan 40. Sementara 8 indikator yang lain masuk dalam prioritas rendah.

Dari permasalahan utama di prodi Pendidikan kimia, perlu dilakukan evaluasi tentang penguatan materi dan optimalisasi dari pembelajaran yang diberikan. Selain itu, yang perlu diperbaiki atau masih dirasa kurang memuaskan dari mahasiswa adalah perlengkapan fasilitas yang diberikan seperti referensi di perpustakaan, tempat ibadah, kelengkapan dan kejelasan informasi terkait kurikulum serta kemudahan dalam proses pengambilan mata kuliah.

Dari aspek empathy hampir secara keseluruhan mahasiswa masih kurang puas sehingga perlu adanya evaluasi hubungan antara pihak prodi dengan mahasiswa. Prodi kimia merupakan prodi yang termuda sehingga nilai keyakinan mahasiswa diprodi setelah ketrima adalah sebesar 69.06. Akan tetapi, kepuasan mahasiswa diprodi sudah cukup besar yakni sebesar 75.78. Dari kuesioner juga diperoleh beberapa harapan yang dituliskan langsung oleh mahasiswa, yang secara umum hasilnya adalah diperlihatkan pada gambar 5.

Kendati demikian, secara keseluruhan permasalahan key-in dan komunikasi dengan pihak orangtua/keluarga mahasiswa 
berdasarkan data yang diperoleh masih menjadikan permasalahan yang harus diperbaiki. Sementara aspek yang lain seperti reliability (dosen), tanglibes, dan informasi secara rata-rata sudah masuk dalam kategori memuaskan mahasiswa. Berdasarkan hal tersebut, kedepannya pihak prodi maupun fakultas dapat bertahap dalam penyelesaian permasalahan tersebut.

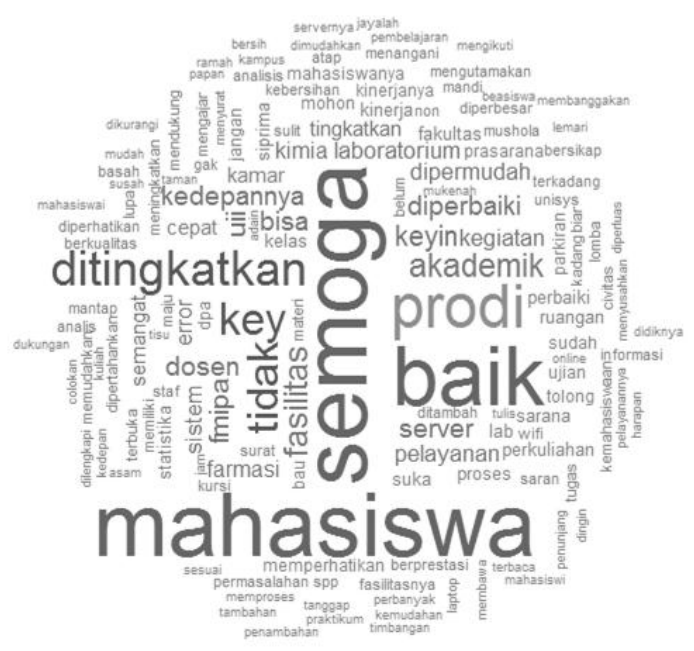

Gambar 5. Gambaran umum saran mahasiswa MIPA

Kemudian dari gambaran umum tersebut, dilakukan analisis dengan melihat asosiasi dari kata yang sering banyak muncul. Diperoleh hasil sebagai berikut:

Dari kata "semoga" asosiasinya terdapat kata baik, bekualitas, berprestasi, keramahannya maka dapat disimpulkan beberapa mahasiswa mengharapkan semoga lebih baik, semoga lebih berkualitas, semoga tidak bermasalah, semoga meningkat keramahannya.

Asosiasi kata "baik" yaitu ada kata "semoga" "kedepannya" "berpedoman" "berwawasan" "islam" maka dapat kita simpulkan bahwa saran dari mahasiswa berharap semoga prodi baik kedepannya, semoga prodi baik, berwawasan dan berpedoman dan seterusnya.

Asosiasi kata "prodi" ada kata membanggakan, adil, berkualitas, berprestasi, dan seterusnya sehingga diharapakan prodi semakin membanggakan, adil, serta berprestasi kedepannya.

\section{Kesimpulan dan Saran}

Tingkat kepuasan di lingkungan fakultas MIPA sebesar 90\% mahasiswa sudah puas atau masuk dalam kategori prioritas prestasi. Kendati demikian, masih terdapat 2 indikator yang harus diperbaiki yakni proses pengambilan mata kuliah (key-in) dan proses komunikasi/koordinasi orangtua dengan pihak Fakultas. Kemudian, diperoleh tingkat keyakinan mahasiswa MIPA tergolong besar dengan nilai 77.38 serta nilai tingkat kepuasan sebesar 78.81 . Dari hasil kuesioner juga dianalisis menggunakan text mining terkait harapan dari mahasiswa MIPA yakni 
prodi dilingkungan MIPA semakin membanggakan, adil, serta berprestasi kedepannya.

\section{Ucapan Terimakasih}

Terimakasih diberikan kepada Direktorat Penelitian dan Pengabdian Masyarakat Universitas Islam Indonesia (DPPM UII) atas terselenggaranya penelitian ini dalam program hibah penelitian institusi tahun 2018.

\section{Daftar Pustaka}

Joshi, A., Kale, S., Chandel, S., \& Pal, D. (2015). Likert Scale: Explored and Explained. British Journal of Applied Science \& Technology, 396-403.

Kartono, K. (1987). Pemimpin dan Kepemimipnan: Apakah Kepemimpinan itu Abnormal. Jakarta: Rajawali.

Mittal V \& Kamakura, W. (2001). Satisfaction, Repurchase Intent, and Repurchase Behavior: Investigating the Moderating Effect of Customer Characteristics. Journal of Marketing Research, Vol. 38(1), 131-142.

Motefakker, N. (2016). The Study of the Level of Satisfaction of the Students of the Faculty of Social Sciences with Welfare Services of Imam Khomeini International University of Qazvin. Procedia Economics and Finance, 399-407.

Nassaji, H. (2015). Qualitative and descriptive research: Data type versus data analysis. Language Teaching Research, pp. 129-132.
Nasution, M. (2001). Manajemen Kualitas Terpadu. Jakarta: Ghalia Indonesia.
P.Kotler. (2000). Marketing Management. New Jersey: Prentice-Hall International,Inc.

Parasuraman A., Z. B. (1985). A conceptual model of service quality and implications for future research. Journal of Marketing, Vol.49,Fall, 41-50.

Rahmawati, D. (2013). Analisis Faktorfaktor yang Mempengaruhi Kepuasan Mahasiswa. Jurnal Economia Vol.9,No.1, 52-65.

Siami, S., \& Gorji, M. (2012). The measurement of service quality by using SERVQUAL and quality gap model. Indian Journal of Science and Technology Vol.5 No.1, 1956-1960.

Supranto, J. (2006). Pengukuran Tingkat Kepuasan Pelanggan untuk Menaikan Pangsa Pasar. Jakarta: Rineka Cipta.

Suryana, D. (2014). Kepuasan Mahasiswa Terhadap Pelayanan Akademik di Jurusan Pendidikan Guru Pendidikan Anak Usia Dini Fakultas Ilmu Pendidikan Universitas Negeri Padang. Padang: Universitas Negeri Padang.

Wei, C. C., \& Ramalu, S. S. (2011). Students Satisfaction towards the University: Does Service Quality Matters? International Journal of Education Vol.3,No.2:E 15, 1-15.

Yamane, T. (1967). Statistics, An Introductory Analysis, 2nd Ed. New York: Harper and Row. 